\title{
Carrot Purple Leaf: A New Spiroplasmal Disease Associated with Carrots in Washington State
}

\author{
Ing-Ming Lee and Kristi D. Bottner, Molecular Plant Pathology Laboratory, USDA-ARS, Beltsville, MD 20705; \\ Joseph E. Munyaneza, Yakima Agricultural Research Lab, USDA-ARS, Wapato, WA 98951; Robert E. Davis, Mo- \\ lecular Plant Pathology Laboratory, USDA-ARS, Beltsville, MD 20705; James M. Crosslin, Vegetable and Forage \\ Crops Research Unit, USDA-ARS, Prosser, WA 99350; Lindsey J. du Toit, Washington State University - NWREC, \\ Mount Vernon 98273; and Todd Crosby, Mercer Ranch, Prosser, WA 99350
}

\begin{abstract}
Lee, I.-M., Bottner, K. D., Munyaneza, J. E., Davis, R. E., Crosslin, J. M., du Toit, L. J., and Crosby, T. 2006. Carrot purple leaf: A new spiroplasmal disease associated with carrots in Washington State. Plant Dis. 90:989-993.

During the growing seasons of 2003 and 2004, a disease occurred in several carrot crops in south central Washington with symptoms suggestive of infection by phytopathogenic mollicutes (phytoplasmas and spiroplasmas). In the fall, many affected carrot plants exhibited extensive purple or yellow-purple leaf discoloration, general stunting of shoots and taproots, and formation of bunchy, fibrous secondary roots. For detection of the putative causal agents, polymerase chain reaction (PCR) assays were performed using primers specific to phytoplasmas as well as primers specific to plant-pathogenic spiroplasmas. Restriction fragment length polymorphism (RFLP) analyses of PCR-amplified $16 \mathrm{~S}$ rDNA sequences revealed that about $81 \%$ of affected plants showing dark purple or yellow-purple leaf symptoms tested positive for Spiroplasma citri. Of affected plants showing mild purple discoloration of leaf margins, $18 \%$ tested positive for a phytoplasma strain belonging to the clover proliferation group (16SrVI), subgroup 16SrVI-A, and $11 \%$ for another phytoplasma strain belonging to the aster yellows group (16SrI), subgroup 16SrI-A. Nucleotide sequence analysis of cloned 16S rDNA confirmed the phytoplasma group affiliations. Some symptomatic plants were co-infected with $S$. citri and either aster yellows phytoplasma or clover proliferation group phytoplasma. To our knowledge, this is the first documentation of spiroplasma infection of carrot in the United States.
\end{abstract}

Additional keyword: BLTVA

Aster yellows and beet leafhoppertransmitted virescence agent (BLTVA) yellows are phytoplasma diseases that affect a wide variety of wild and cultivated plant species, including many umbelliferous crops such as carrot (Daucus carota L. subsp. sativus (Hoffm.) Arcang.; 1). Aster yellows and BLTVA yellows are caused by two genetically distinct phytoplasmas. Aster yellows is caused by a phytoplasma in the aster yellows group, 16SrI, and is the most common phytoplasma disease of carrot in the United States $(14,18)$. BLTVA yellows in carrot is caused by a phytoplasma in subgroup A of the clover proliferation group $16 \mathrm{SrVI}$ (26), and has only

Corresponding author: I.-M. Lee

E-mail: leeim@ba.ars.usda.gov

Accepted for publication 2 March 2006.

DOI: $10.1094 /$ PD-90-0989

This article is in the public domain and not copyrightable. It may be freely reprinted with customary crediting of the source. The American Phytopathological Society, 2006. been reported in the western United States (1).

Symptoms caused by aster yellows and BLTVA yellows in carrot are very similar. The aster yellows phytoplasma initially causes yellowing of leaf veins, which progresses to chlorosis of entire leaves; formation of upright, chlorotic adventitious shoots; mild bronzing, reddening, or purpling of older leaves; and reduction in size and quality of taproots with proliferation of secondary roots. Late in the growing season, flowers of infected plants display phyllody (formation of leaf-like petals on the flowers) and virescence (greening of the flowers), with stunting and chlorosis of the plants (1). Infection of carrot plants by the BLTVA yellows phytoplasma results in mild chlorosis and reddening or purpling of the lower leaves; development of a thin, woody taproot with excessive proliferation of side roots; and premature flowering of plants early in the growing season with proliferation of compound, leafy umbels that display virescence and phyllody (1). Although aster yellows and BLTVAinfected plants have been found in the same carrot field, co-infection of a plant with both phytoplasmas has not been demonstrated (1).

Over the past decade, a phytoplasma yellows-like disease has been observed in several processing carrot crops in south central Washington. Symptoms included yellow, bronze, and purple discoloration of foliage (Fig. 1A to C), general stunting or rosette formation of shoots and taproots (Fig. 1B), and formation of multiple taproots (Fig. 1C) and/or bunchy, fibrous secondary roots (Fig. 1D). The incidence of symptomatic plants in individual fields was $<5 \%$ in nonepidemic years but as high as $100 \%$ in one crop in 2002 , resulting in significant economic losses in processing carrot crops in this region of Washington. Although symptoms were typical of yellows diseases caused by phytopathogenic mollicutes, i.e., phytoplasmas and spiroplasmas, they were distinct from those typically caused by aster yellows or BLTVA yellows phytoplasma strains in that infected carrot plants did not develop adventitious shoots, virescence, or phyllody symptoms typically associated with aster yellows or BLTVA yellows. Initial polymerase chain reaction (PCR) assays using primer pair P1/P7 (14) for detection of phytoplasmas yielded negative results in all samples tested. As a result, additional assays were carried out to detect strains of both phytoplasmas and spiroplasmas. The objective of this study was to use PCR primers for phytoplasmas as well as PCR primers for spiroplasmas to determine the cause of the symptoms observed in processing carrot crops in south central Washington. Preliminary results have been presented (11).

\section{MATERIALS AND METHODS}

Carrot samples. Leaf and root tissues were sampled from a total of 59 symptomatic carrot plants collected in three locations within a 30- to 50-mile radius in the Columbia Basin of south central Washington in October of 2003, and May and October of 2004 (Table 1). In addition, several asymptomatic plants were sampled from each site to serve as control plants. 
Insect collection. In 2003, leafhoppers were collected using sweep nets from May to November at several locations throughout the south Columbia Basin region of Washington near affected carrot fields, including Alderdale, Pasco, and Prosser. Leafhoppers were identified and preserved in $70 \%$ ( $\mathrm{vol} / \mathrm{vol})$ ethanol. The populations of two leafhopper species (Circulifer tenellus and Macrosteles sp.) collected at different sampling dates were determined.

PCR and restriction fragment length polymorphism (RFLP) analysis. Total nucleic acid was extracted from $0.5 \mathrm{~g}$ of leaf petioles or vascular tissue of the taproot of each of the 59 carrot samples according to a modified procedure using the DNeasy Plant Mini Kit (Qiagen, Valencia, CA) as described by Green et al. (9). A nested PCR assay using primer pair P1/16S-Sr (5'-AAGAGTTTGATCCTGGC TCAGGATT-3'/5'-GGTCTGTCAAAACT GAAGATG-3') in the first amplification followed by $\mathrm{R} 16 \mathrm{~F} 2 \mathrm{n} / \mathrm{R} 16 \mathrm{R} 2 \mathrm{n}$ (5'-GAA ACGACTGCTAAGACTGG-3'/5'-TGACG
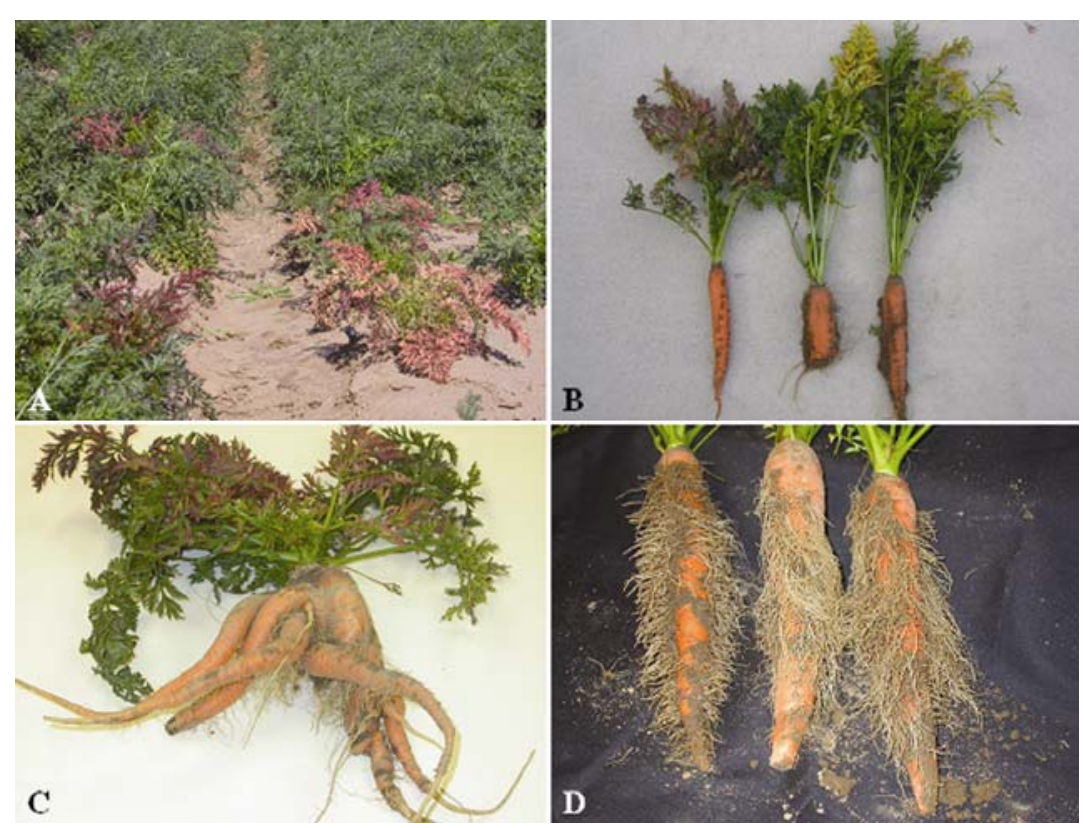

Fig. 1. Symptoms of carrot plants infected with Spiroplasma citri: A, purple foliage discoloration of infected plants with asymptomatic plants in the background; B, yellow and bronze foliage discoloration and general stunting of shoots and taproots; C, formation of secondary taproots; $\mathbf{D}$, formation of long, bunchy, fibrous secondary roots.

GGCGGTGTGTACAAAC-3') $(13,15)$ in the second amplification was performed to detect phytoplasmas in the carrot samples. A negative control, devoid of DNA templates in the reaction mix, was included in all PCR assays. For PCR amplification, 38 cycles were conducted in an automated thermal cycler (MJ Research DNA Thermal Cycler PTC-200) with AmpliTaq Gold polymerase (Applied Biosystems, Foster City, CA). PCR was carried out in $25-\mu l$ reaction mixtures containing $1 \mu \mathrm{l}$ of undiluted nucleic acid preparation (100 to 200 $\mathrm{ng}), 200 \mu \mathrm{M}$ of each dNTP, and $0.4 \mu \mathrm{M}$ of each primer. The following conditions were used: denaturation at $94^{\circ} \mathrm{C}$ for $1 \mathrm{~min}$ (11 min for the first cycle to activate AmpliTaq Gold polymerase), annealing for 2 min at $55^{\circ} \mathrm{C}$, and primer extension for 3 $\min \left(7 \mathrm{~min}\right.$ in the final cycle) at $72^{\circ} \mathrm{C}$. The P1/16S-Sr PCR yielded an amplicon that included near full-length 16S rDNA (about $1.5 \mathrm{~kb})$. One microliter of diluted $(1: 30)$ PCR product from the first amplification was used as the template in the reaction

Table 1. Summary of polymerase chain reaction (PCR) assays of symptomatic carrot plants in the Columbia Basin of Washington State using phytoplasma and Spiroplasma citri specific primers

\begin{tabular}{|c|c|c|c|c|c|c|}
\hline \multirow[b]{2}{*}{ Carrot cultivar } & \multirow{2}{*}{$\begin{array}{l}\text { Location and date } \\
\text { samples collected }\end{array}$} & \multicolumn{2}{|c|}{ S. citri $16 \mathrm{~S}$ rDNA-based primers } & \multirow{2}{*}{$\begin{array}{c}\text { S. citri } \\
\text { viral-based } \\
\text { primer }\end{array}$} & \multicolumn{2}{|c|}{ Phytoplasma 16S rDNA-based primers } \\
\hline & & Direct PCR & Nested PCR & & Direct PCR & Nested PCR \\
\hline Multiple cultivars & S. Columbia Basin, Oct. 2003 & $4 / 8^{a}$ & $6 / 8$ & $7 / 8$ & $0 / 8$ & $0 / 8$ \\
\hline Enterprise & Alderdale, WA, Oct. 2004 & $4 / 5$ & $4 / 5$ & $4 / 5$ & $0 / 5$ & $0 / 5$ \\
\hline Cheyenne & Alderdale, WA, Oct. 2004 & $4 / 8$ & $7 / 8$ & $8 / 8$ & $4 / 8$ & $4 / 8$ \\
\hline Sun 255 & Alderdale, WA, Oct. 2004 & $1 / 9$ & $5 / 9$ & $6 / 9$ & $2 / 9$ & $4 / 9$ \\
\hline Red Core Chantenay & Pasco, WA, May 2004 & $5 / 14$ & $12 / 14$ & $11 / 14$ & $\mathrm{nd}^{\mathrm{b}}$ & nd \\
\hline Multiple cultivars & Prosser, WA, Oct. 2004 & $10 / 15$ & $14 / 15$ & nd & $2 / 15$ & $5 / 15$ \\
\hline Total & & $28 / 59$ & $48 / 59$ & $36 / 44$ & $8 / 45$ & $13 / 45$ \\
\hline
\end{tabular}

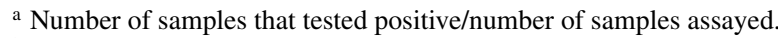

b Not determined. 
tively, were used as reference strains for the RFLP analyses. Separation and visualization of the restriction products were performed as described above.

Cloning and sequencing of PCR amplified products. ScR16F1A/ScR16R2 products were purified using PCR Kleen Spin Columns (Bio-Rad, Hercules, CA) and cloned into Escherichia coli using the TOPO-TA Cloning Kit (Invitrogen, Carlsbad, CA) according to manufacturers' instructions. Sequencing was performed with an automated DNA sequencer (ABI 3730; Center for Biosystems Research, University of Maryland, College Park). Sequences were submitted to GenBank and assigned the following accession numbers: DQ112019 for S. citri Car4 and DQ112020 for S. citri Car6.

\section{RESULTS AND DISCUSSION}

Both spiroplasmas and phytoplasmas were detected in symptomatic carrot plants sampled from six carrot crops in the southern Columbia Basin of Washington. S. citri was found in each of the six fields sampled, and phytoplasmas were found in three of five fields sampled. To our knowledge, this is the first report of natural infection of carrot by $S$. citri. Symptomless samples tested negative for both $S$. citri and the aster yellows and BLTVA phytoplasmas. Of a total of 59 plant samples collected in 2003-2004 in these carrot fields, $48(81.3 \%)$ tested positive for $S$. citri, eight $(17.8 \%$ based on 45 samples tested) tested positive for BLTVA phytoplasma (16SrVI-A), and five (11.1\% based on 45 samples tested) tested positive for aster yellows phytoplasma (16SrI-A), based on nested PCR assays using the appropriate $16 \mathrm{~S}$ rDNA-based primer pairs (Table 1). PCR analysis using the spiroplasma virus-based primers confirmed a high incidence of $S$. citri (Table 1). S. citriinfected carrot plants exhibited distinct yellow, bronze, and purple foliage discoloration (Fig. 1A to C), with some of the infected plants also developing fibrous secondary roots (Fig. 1D) or multiple taproots (Fig. 1C). RFLP analyses of PCRamplified 16S rDNA sequences digested with the restriction enzymes AluI, HhaI, HaeIII, and MseI indicated that sequences obtained from the carrot samples which tested positive for $S$. citri had identical restriction profiles to those of the $S$. citri reference strain with all four enzymes and had a different profile from that of the $S$. kunkelii reference strain with HhaI (Fig. 2A). Nucleotide sequence analysis of cloned 16S rDNAs from several samples confirmed that the $S$. citri strains in the diseased carrot plants were very closely related to an S. citri strain (Maroc, ATCC 27556) that causes citrus stubborn disease, sharing more than $99.5 \%$ sequence homology (GenBank accession no. M22942). RFLP analyses of 16S rDNA sequences with four enzymes $(A l u \mathrm{I}, M s e \mathrm{I}, H h a \mathrm{I}$, and
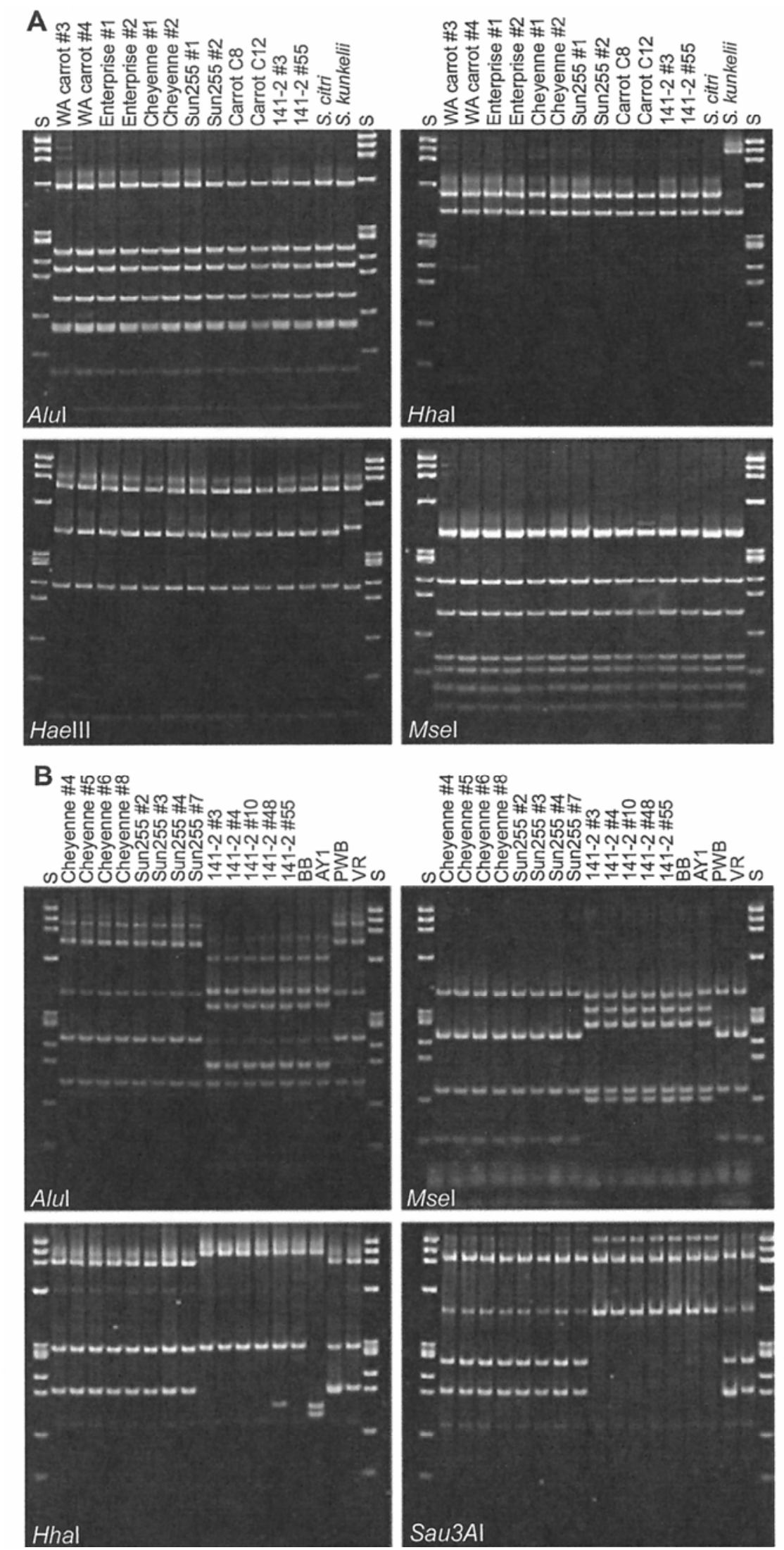

Fig. 2. A, Restriction fragment length polymorphism (RFLP) analyses of 16S rDNA amplified by nested polymerase chain reaction (PCR) with Spiroplasma citri 16S rDNA-based primers. Products from nested PCR assays using primer pair SCR16F1A/ScR16R2 were digested with restriction enzymes AluI, HhaI, HaeIII, and MseI. B, RFLP analyses of 16S rDNAs amplified by nested PCR using phytoplasma 16S rDNA-based primer pair R16F2n/R16R2. PCR products were digested with restriction enzymes AluI, HhaI, Sau3AI, and MseI. Digests were separated by electrophoresis through 5\% polyacrylamide gels. Lane S: ØX 174 RF1 DNA HaeIII digest, fragment sizes (bp) from top to bottom: $1,353,1,078,872,603,310,281,271,234,194$, and 72 . 
Sau3A) revealed that eight (four Cheyenne and four Sun 255) out of 13 phytoplasmapositive plants were infected by phytoplasma strains belonging to the clover proliferation phytoplasma subgroup A (16SrVI-A) as indicated by RFLP profiles very similar or identical to those of two 16SrVI-A reference strains (PWB and VR), while five plants (multiple cultivars sampled from Prosser, WA) were infected by phytoplasma strains belonging to the aster yellows phytoplasma subgroup A (16SrI-A) as indicated by profiles identical to those of the $16 \mathrm{SrI}-\mathrm{A}$ reference strain $\mathrm{BB}$ (Fig. 2B). Several samples were coinfected with $S$. citri and either BLTVAlike phytoplasma or aster yellows phytoplasma, but none was co-infected with the two types of phytoplasma. This is the first report that group 16SrI, subgroup 16SrI-A, is present in the western coastal states of the United States.

The results of this study revealed that $S$. citri was the primary pathogen detected in the carrot samples that showed symptoms of general stunting, rosette formation, yellow-purple discoloration on leaf margins, and dark purple leaves and petioles. The affected plants also exhibited excess fibrous secondary roots or multiple taproots. S. citri was detected in all of the carrot samples that had severe purple leaf syndrome, while BLTVA yellows and aster yellows phytoplasmas were only detected in samples showing mild symptoms of light purple discoloration on the leaf margins. The mild symptoms may be attributed to late infection of the plants by phytoplasmas. BLTVA yellows phytoplasma can cause premature flowering and virescence in infected carrots $(1,26)$. Aster yellows phytoplasma-infected carrots develop extensive shoot proliferation and phyllody symptoms in later stages of infection

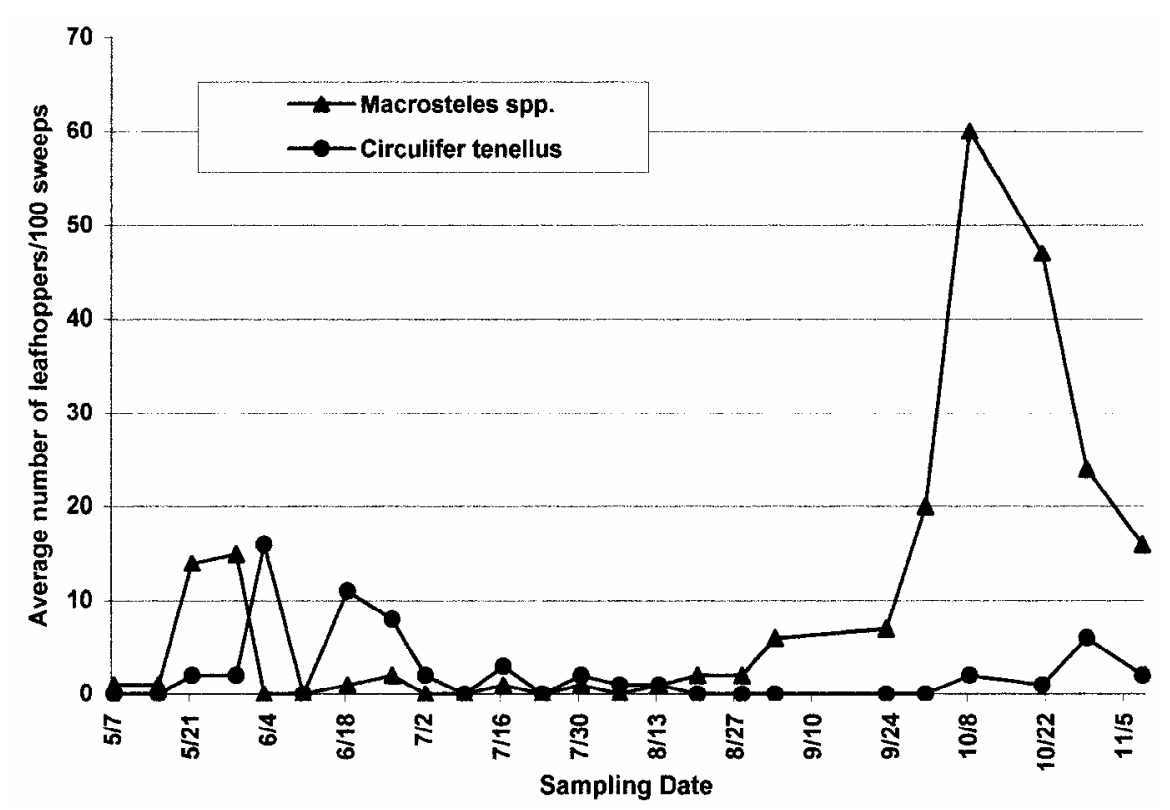

Fig. 3. Population dynamics of two leafhopper species, Macrosteles spp. and Circulifer tenellus, near infected carrot fields in the southern Columbia Basin region in 2003.

$(1,14)$. Initial symptoms caused by $S$. citri and aster yellows or BLTVA phytoplasmas may be indistinguishable. However, in the later stages of infection by $S$. citri, infected carrots exhibited foliar symptoms characterized by general stunting and leaf discoloration, and a lack of shoot proliferation and phyllody.

In nature, $S$. citri and BLTVA yellows phytoplasma are transmitted by the beet leafhopper, Circulifer tenellus (Baker) $(2,5,8,16,27)$. Both are important pathogens in the western coastal states. These pathogens have wide but different host ranges, and cause several economically important diseases, including citrus stubborn (caused by $S$. citri), tomato big bud (caused by BLTVA yellows phytoplasma), potato purple top (caused by BLTVA yellows phytoplasma), and diseases in Brassicaceae vegetable crops (caused by $S$. citri or BLTVA yellows phytoplasma) in California, Oregon, and Washington $(3,7,12$, 22-26). Potato purple top has recently become epidemic in the Columbia Basin of northern Oregon and Washington (12). The primary factors that determine the range of diverse natural plant hosts inhabited by these two pathogens are unknown. The natural plant host ranges of the two pathogens may be determined by interactions of the pathogen(s), vector, and host(s), with differential susceptibility of a plant host species to each pathogen as well as vector feeding preferences serving as primary determining factors.

Carrot has never been reported to be a preferred natural host of beet leafhoppers and was shown to be unable to support beet leafhopper colonies under experimental conditions (20). Beet leafhoppers migrate in late spring and early summer after crops, including many preferred hosts of this vector, have been harvested. There-

992 Plant Disease / Vol. 90 No. 8 fore, beet leafhoppers may be transient feeders on carrot. Several brassicaceous and chenopodiaceous species collected during the summer of 2004 from the southern Columbia Basin region, including turnip, radish, and chard, were found to be infected with $S$. citri or BLTVA yellows phytoplasma (J. M. Crosslin, unpublished). These infected vegetables could have served as the source from which the beet leafhoppers acquired both pathogens.

A survey of beet leafhopper populations in fields in the southern Columbia Basin at various times throughout the growing season indicated that beet leafhoppers were prevalent during the months of May and June and, to a lesser extent, in October, while the populations of Macrosteles spp. peaked during the months of May, October, and November (Fig. 3). This seemed to be consistent with the appearance of infected carrots in late spring or fall. Preliminary PCR assays indicated that only beet leafhoppers carried BLTVA yellows phytoplasma and/or S. citri (5; J. M. Crosslin, unpublished). The different incidences of the two pathogens detected in carrot samples collected from different fields and at different times in the growing season in Washington may reflect different incidences of the pathogens carried by the beet leafhoppers that fed on the plants. Alternatively, carrot may be differentially susceptible to the two pathogens.

The presence of the third pathogen, aster yellows phytoplasma, may provide clues to the spread of $S$. citri in carrot crops. Aster yellows phytoplasma is carried by leafhoppers of the genus Macrosteles, which have also been shown experimentally to be capable of acquiring and transmitting $S$. citri $(17,21)$. Since Macrosteles spp. were abundant in the carrot fields sampled in October and November in Washington and carrot is a preferred host of this leafhopper, Macrosteles spp. may have contributed to the high incidence of $S$. citri detected.

Carrot purple leaf represents yet another economically important disease caused by S. citri. The most economically important disease caused by $S$. citri to date has been citrus stubborn, which is widespread in central and southern California and causes severe loss in the citrus industry $(2,3)$. The beet leafhopper is abundant in California as well as in Oregon and Washington $(4,6,10,19)$. Thus it is surprising that $S$. citri has never been reported to cause disease in carrots in California. If carrot purple leaf has mistakenly been attributed to the aster yellows phytoplasma in the past, the severity and economic importance of $S$. citri in the western coastal states may have been underestimated.

\section{LITERATURE CITED}

1. Blomquist, C. L. 2002. Aster yellows and beet leafhopper-transmitted virescence agent yellows. Pages 58-59 in: Compendium of Umbelliferous Crop Diseases. R. M. Davis and R. N. Raid, eds. American Phytopathological So- 
ciety, St. Paul, MN

2. Calavan, E. C., Kaloostian, G. H., Oldfield, G. N., Nauer, E. M., and Gumpf, D. J. 1977. Natural spread of Spiroplasma citri by insect vectors and its implications for control of stubborn disease of citrus. Proc. Int. Soc. Citric. 3:900-902

3. Calavan, E. C., and Oldfield, G. N. 1979. Symptomatology of spiroplasmal plant diseases. Pages 37-64 in: The Mycoplasmas: Plant and Insect Mycoplasmas. Vol. III. R. F. Whitcomb and J. G. Tully, eds. Academic Press, New York.

4. Cook, W. C. 1967. Life history, host plants, and migrations of the beet leafhopper on the western United States. U.S. Dep. Agric. Tech. Bull. 1365 .

5. Crosslin, J. M., Munyaneza, J. E., Jensen, A., and Hamm, P. B. 2005. Association of beet leafhopper (Hemiptera: Cicadellidae) with a clover proliferation group phytoplasma in $\mathrm{Co}-$ lumbia Basin of Washington and Oregon. J. Econ. Entomol. 98:279-283.

6. Douglass, J. R., Peay, W. E., and Cowger, J. I. 1956. Beet leafhopper and curly top conditions in the southern Great Plains and adjacent areas. J. Econ. Entomol. 49:95-99.

7. Fletcher, J., Schultz, G. A., Davis, R. E., Eastman, C. E., and Goodman, R. M. 1981. Brittle root disease of horseradish: Evidence for an etiological role of Spiroplasma citri. Phytopathology 71:1073-1080.

8. Golino, D. A., Oldfield, G. N., and Gumpf, D. J. 1989. Experimental hosts of the beet leafhopper-transmitted virescence agent. Plant Dis. 73:850-854.

9. Green, M. J. Thompson, D. A., and MacKenzie, D. J. 1999. Easy and efficient DNA extraction from woody plants for the detection of phytoplasmas by polymerase chain reaction. Plant Dis. 83:482-485.

10. Hills, O. A. 1937. The beet leafhopper in the central Columbia River breeding area. J. Agric. Res. 55:21-31.

11. Lee, I., Bottner, K., Munyaneza, J., Davis, R., Crosslin, J., du Toit, L., and Crosby, T. 2005. Carrot purple leaf: A new carrot disease asso- ciated with Spiroplasma citri and phytoplasmas in Washington. (Abstr.) Phytopathology 95:S57.

12. Lee, I.-M., Bottner, K. D., Munyaneza, J. E., Secor, G. A., and Gudmestad, N. C. 2004. Clover proliferation group (16SrVI) subgroup A (16SrVI-A) phytoplasma is a probable causal agent of potato purple top disease in Washington and Oregon. Plant Dis. 88:429.

13. Lee, I.-M., Gundersen-Rindal, D. E., Davis, R. E., and Bartoszyk, I. M. 1998. Revised classification scheme of phytoplasmas based on RFLP analyses of 16S rRNA and ribosomal protein gene sequences. Int. J. Syst. Bacteriol. 48:1153-1169.

14. Lee, I.-M., Martini, M., Bottner, K. D., Dane, R. A., Black, M. C., and Troxclair, N. 2003. Ecological implications from a molecular analysis of phytoplasmas involved in an aster yellows epidemic in various crops in Texas. Phytopathology 93:1368-1377.

15. Lee, I.-M., Martini, M., Marcone, C., and Zhu, S. F. 2004. Classification of phytoplasma strains in the elm yellows group (16SrV) and proposal of 'Candidatus Phytoplasma Ulmi' for the phytoplasma associated with elm yellows. Int. J. Syst. Bacteriol. 54:337-347.

16. Liu, H.-Y. 1981. The transmission, multiplication, and electron microscopic examination of Spiroplasma citri in its vector, Circulifer tenellus. Ph.D. thesis. University of California, Riverside.

17. Maramorosch, K., and Kondo, F. 1978. Aster yellows spiroplasma: Infectivity and association with a rod-shaped virus. Zentralbl. Bakteriol. Parasitenk. Infektionskr. Hyg., Abt. I Orig., Reihe A 241:196.

18. McCoy, R. E., Caudwell, A., Chang, C. J., Chen, T. A., Chiykowski, L. N., Cousin, M. T., Dale de Leeuw, G. T. N., Golino, D. A., Hackett, K. J., Kirkpatrick, B. A., Marwitz, R., Petzold, H., Sinha, R. H., Sugiura, M., Whitcomb, R. F., Yang, I. L., Zhu, B. M., and Seemüller, E. 1989. Plant diseases associated with mycoplasmalike organisms. Pages 545-560 in: The Mycoplasmas. Vol. 5. R. F. Whitcomb and J. G. Tully, eds. Academic Press, New York.
19. Munyaneza, J. E. 2005. Purple top disease and beet leafhopper-transmitted virescence agent (BLTVA) phytoplasma in potatoes of the $\mathrm{Pa}$ cific Northwest of the United States. Pages 211-220 in: Potato in Progress: Science Meets Practice. A. J. Haverkort and P. C. Struik, eds. Wageningen Academic Publishers, Wageningen, The Netherlands

20. Munyaneza, J. E., and Upton, J. E. 2005. Beet leafhopper (Hemiptera: Cicadellidae) setting behavior, survival, and reproduction on selected host plants. J. Econ. Entomol. 98:18241830.

21. O’Hayer, K. W., Schultz, G. A., Eastman, C. E., Fletcher, J., and Goodman, R. M. 1983. Transmission of Spiroplasma citri by the aster leafhopper, Macrosteles fascifrons (Homoptera: Cicadellidae). Ann. Appl. Biol. 102:311-318.

22. Oldfield, G. N., and Calavan, E. C. 1982 Stubborn disease in non-rutaceous plants. Description and Illustration of Virus and Viruslike Diseases of Citrus: A Collection of Color Slides (rev. ed.). J. Bové and R. Vogel, eds. Institut Francais de Recherches Fruitieres OutreMer. Paris.

23. Raju, B. C., Nyland, G., Backus, E. A., and McLean, D. L. 1981. Association of a Spiroplasma with brittle root of horseradish. Phytopathology 71:1067-1072.

24. Schultz, T. R., and Shaw, M. E. 1991. Occurrence of the beet leafhopper-transmitted virescence agent in red and daikon radish seed plants in Washington State. Plant Dis. 75:751.

25. Shaw, M. E., and Kirkpatrick, B. C. 1993. The beet leafhopper-transmitted virescence agent causes tomato big bud disease in California Plant Dis. 77:290-295.

26. Shaw, M. E., Kirkpatrick, B. C., Davis, R. M., and Golino, D. A. 1990. The beet leafhopper transmitted virescence agent causes a premature flowering and virescence disease of carrots. (Abstr.) Phytopathology 80:1072.

27. Tsai, J. H. 1979. Vector transmission of mycoplasmal agents of plant diseases. Pages 265 307 in: The Mycoplasmas, Vol. 3. R. E. Whitcomb and J. G. Tully, eds. Academic Press, New York. 